\title{
Assessment of Mercury (Hg) and Cyanide (CN) Pollution in Surfacewaters, Groundwaters and Sediments around Industrial Mining Sites in the Department of Divo (Ivory Coast)
}

\author{
Yao Kouassi Serge Aristide, Ahoussi Kouassi Ernest \\ Training and Research Unit for Earth Sciences and Mining Resources, Soil, Water and Geomaterials Laboratory, Université Félix \\ Houphouët-Boigny, Abidjan, Ivory Coast \\ Email: yyserge0@gmail.com, akouassiernest@gmail.com
}

How to cite this paper: Aristide, Y.K.S. and Ernest, A.K. (2021) Assessment of Mercury $(\mathrm{Hg})$ and Cyanide $(\mathrm{CN})$ Pollution in Surfacewaters, Groundwaters and Sediments around Industrial Mining Sites in the Department of Divo (Ivory Coast). Journal of Water Resource and Protection, 13, 75-91. https://doi.org/10.4236/jwarp.2021.132005

Received: November 26, 2020

Accepted: February 1, 2021

Published: February 4, 2021

Copyright $\odot 2021$ by author(s) and Scientific Research Publishing Inc. This work is licensed under the Creative Commons Attribution International License (CC BY 4.0).

http://creativecommons.org/licenses/by/4.0/

\begin{abstract}
Contamination of water and sediments by trace metal elements constitutes a risk to water, living species and for human health. The objective of this study is to assess the level of contamination of water and sediments in the Divo mining area with trace elements. Trace elements ( $\mathrm{CN}$ and $\mathrm{Hg}$ ) were determined in water and sediments using an Inductive Coupled Plasma Atomic Emission Spectrometer (ICP-AES). The intensity of sediment contamination was estimated from the calculation of several indices, including the Contamination Factor (FC), the Modified Contamination Degree $\left(\mathrm{DC}_{\mathrm{m}}\right)$ and the Sediment Pollution Index (SPI). The results of the monitoring of the seasonal evolution of TME (CN and Hg), during the months of September 2018 and February 2020 are as follows: In surface water, the metallic concentrations vary from 0 to $4.98 \mu \mathrm{g} / \mathrm{L}$ for mercury and 0 to $95 \mu \mathrm{g} / \mathrm{l}$ for cyanide. All surface water samples have mercury concentrations lower than the average reference concentration of $6 \mu \mathrm{g} / \mathrm{L}$. $7 \%$ of surface water samples have cyanide concentrations above the average concentration of $70 \mu \mathrm{g} / \mathrm{L}$. Concerning groundwater, the cyanide concentrations remained below the standards for drinking water over the two seasons. Mercury recorded high concentrations in wells in the department. The sediments were found to be polluted with $\mathrm{CN}$ (uncontaminated to low contamination/very heavily contaminated) and $\mathrm{Hg}$ (uncontaminated to moderately contaminated/very heavily contaminated). The IPS values show that the surface sediments are moderately polluted except at the HR6 stations (0.07); ZR3 (0.22); AR1 (1.15); R3 (0.96); BRR (0); DRV (0.07) where the sediments are healthy. The inhabitants of mining areas are exposed to the risk of contracting various diseases by consuming this water contami-
\end{abstract}


nated with these trace elements.

\section{Keywords}

Mercury, Cyanide, Sediments, Contamination, Source Apportionment

\section{Introduction}

Extractive industries are essential for the development of national economies. The mining sector plays an important role in the growth of many countries around the world and continues to make an important contribution to national and regional economies [1]. Mercury and cyanide, however are toxic metals, recognized nowadays significant and harmful pollutants for man and the environment [2]. They are naturally present in water but at very low concentrations [3]. However, through industrialization, the industrial mining of gold and silver, man contributes to the increase in the amount of these trace elements in the environment [4]. Recent studies have shown that the amount of mercury in water has increased since the industrial age [5]. Few studies have been conducted on potential contamination of hydrosystems by the use of mercury and cyanide in mining activities, to understand the extent and the depth of the problems associated with industrial mining [6]. It is important to study the levels of mercury and cyanide the sites of industrial min. Most of the communities in the department get their domestic water supplies from boreholes, rivers and streams. Therefore, it is imperative that the levels of mercury and cyanide in these sources are known. Fishing is also a phenomenon running in these rivers and streams. The knowledge of the levels of mercury and cyanide will also inform corrective measures to take before this water is used for any purpose. The objective of this study is to determine the levels of total mercury and cyanide in the rivers, streams, sediments and drillings. Then compare them with [7] guideline values.

\section{Materials and Methods}

\subsection{Study Area}

The study area is located at the western part of Ivory Coast in the department of Divo, about $187 \mathrm{~km}$ from Abidjan, the economic capital. It covers an area of approximately $3577 \mathrm{~km}^{2}$ and is located between the latitudes $05^{\circ} 40^{\prime} \mathrm{N}$ and $06^{\circ} 10^{\prime} \mathrm{N}$ and longitudes $05^{\circ} 30^{\prime} \mathrm{W}$ and $04^{\circ} 40^{\prime} \mathrm{W}$. The department has (07) sub-prefectures including: sub-prefecture of Chiepo, Hiré, Zégo, Didoko, Nébo, Ogoudou and Divo. It is limited by Oumé department to the north, Lakota department to the west, Grand Lahou department to the southeast, Guitry department to the southwest, and Tiassalé department to the east. It is made up of three sub-watersheds: the Bandama and Gô watershed and the Boubo watershed, with the presence of two large mining areas in Hiré and Agbaou. The department consists mostly of old basement rocks and a small portion of coastal sedimentary rocks. The for- 
mations of the basement rocks are Archaean formations (compound gneisses), the bast formations (granitoid) and the formations birimiennes (conglomerates, sandstone and schists). The basement formations are grouped into three main groups, which are the Archean formations (migmatites), the Liberian formations (granitoids) and the Birimian formations (conglomerates, sandstones and schists). The Liberian and Birimian formations were the dominant rock types (Figure 1).

\subsection{Mining Activities in the Department of Divo}

The department has an enormous amount of mineral resources, especially in the commune of Hiré and the locality of Agbaou. These resources are exploited by multinational companies such as: NEWCREST, ANDEAVOR and also in an artisanal way called gold panning (Figure 2). The industrial exploitation of gold in Côte d'Ivoire is carried out through an exploitation with open mines. This mode of exploitation generates major environmental problems, in particular the destruction of the soil, the pollution of waterways, the drying up of underground water tables, and the destruction of plants amongst others.

The department has manyrivers and streams. The gold mining areas where the studywasconducted are drained by the Gnouzalé, Gnénessi, Zessié and Lélébiabarivers. Out of these, severalriverswereselectedbecause of theirstrategic locations in relation to miningactivities and theirpotential impact on the domestic water supply in the area. Twelve boreholes and ninesampledwells are

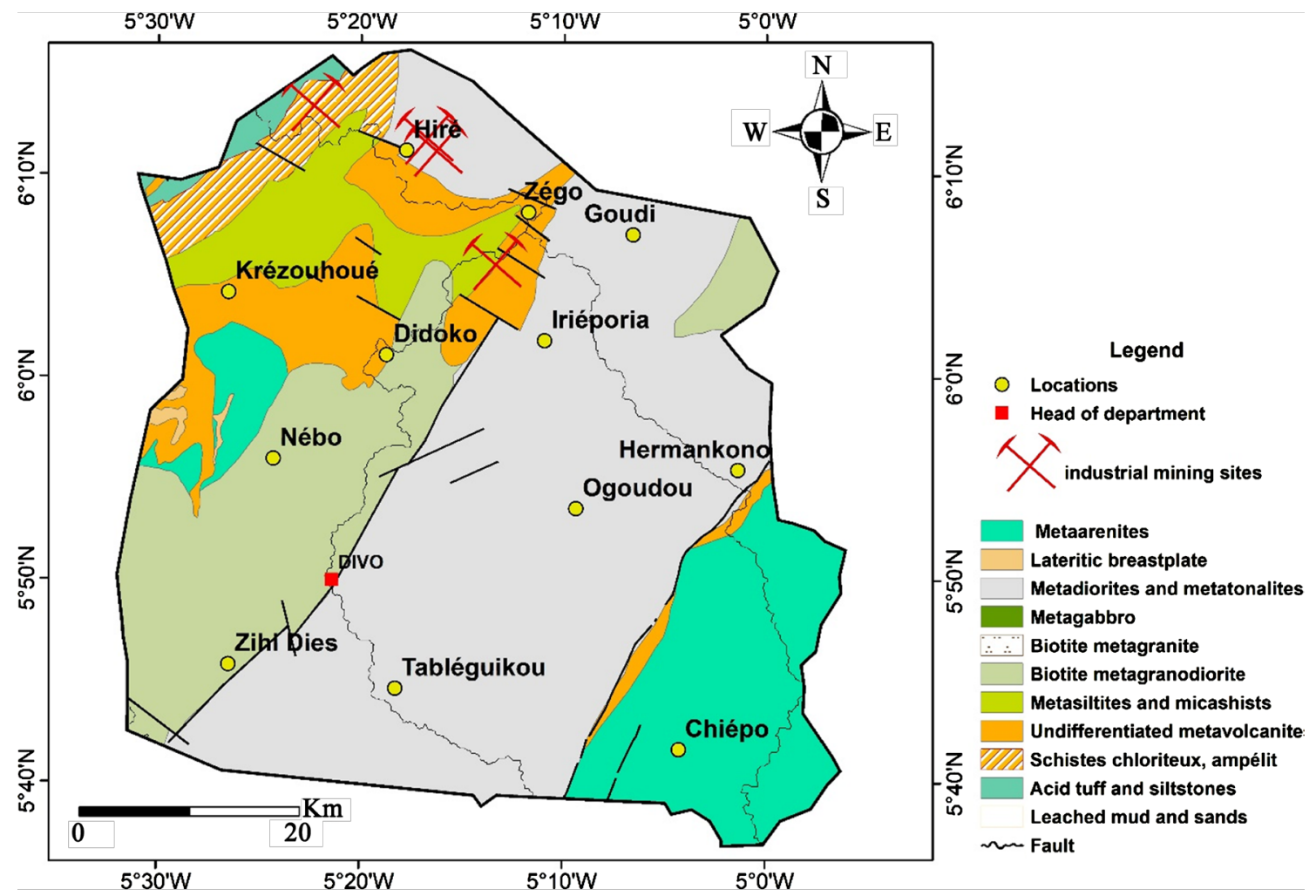

Figure 1. Geological map of the study area. 

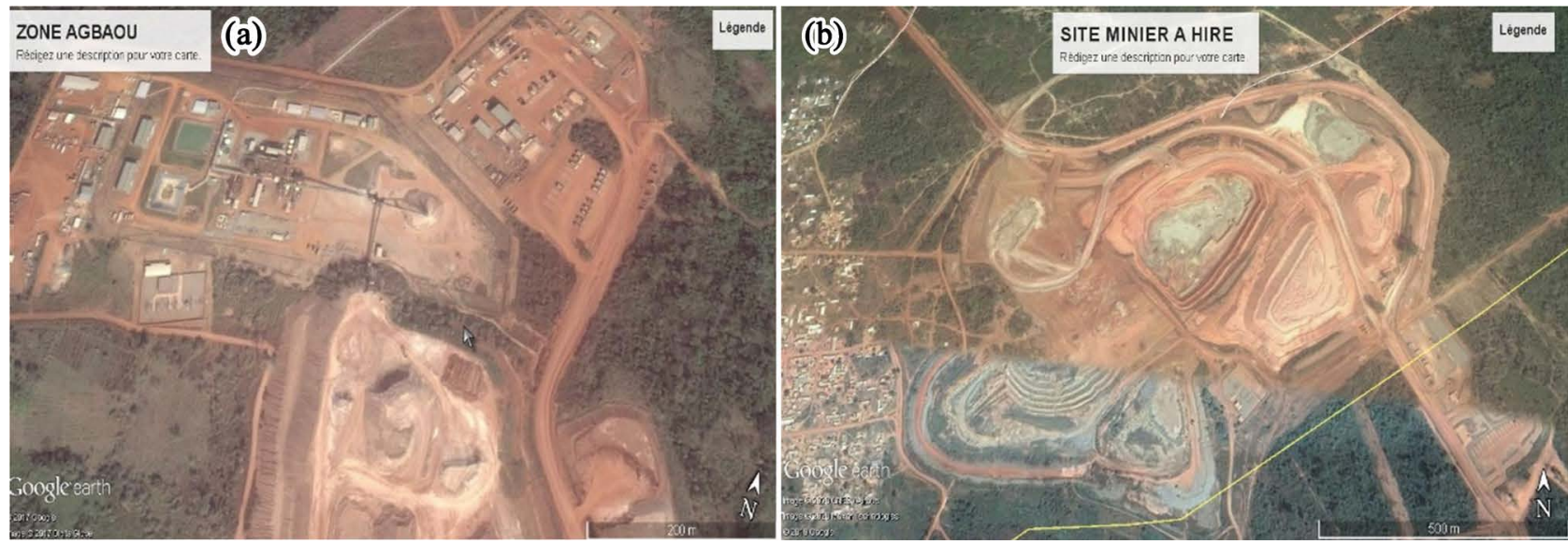

Figure 2. Open-cast mine to AGBAOU (a) and HIRE (b) (Source: Newrest Mining, April 2012; Google map, 2016).

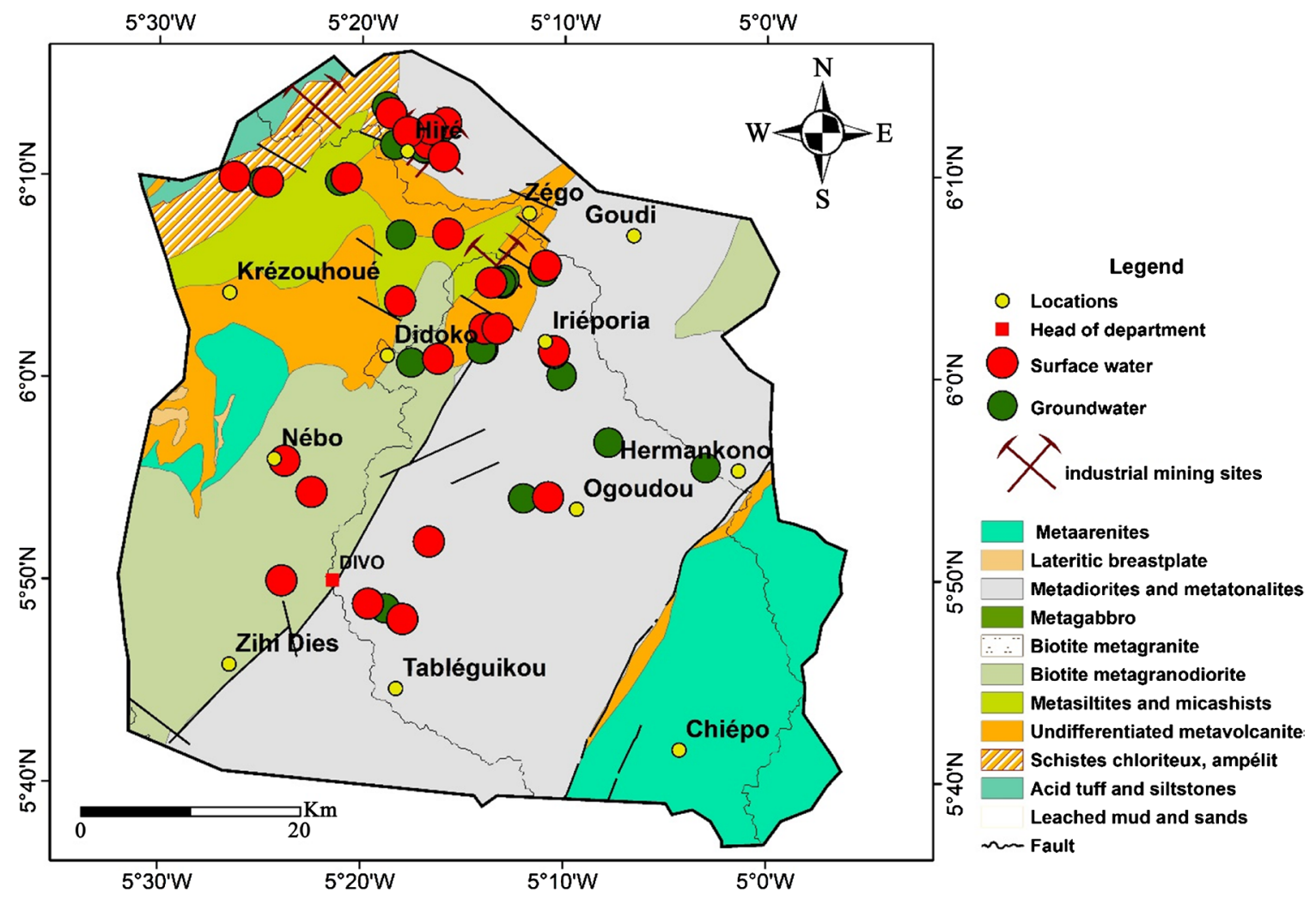

Figure 3. Location of study sites and sampling stations.

located in areas mainlyaffected by miningactivities and outsidemining areas (Figure 3).

\section{Sampling Methodology}

\subsection{Environmental Data Sampling}

Sampling was conducted to cover a period of 18 months. Samples were taken between September, 2018 and February 2020. September is the wet period while February is considered the dry period. Water and sediment sampling points 
were located immediately upstream of areas near mining areas. Sampling points up stream of industrial gold mining areas are located at least $2 \mathrm{~km}$ from gold mining to prevent any possible contamination, while the sampling points located close the mining areas are also about $100 \mathrm{~m}$ away. In the case of the Zéhi River, samples were taken about $200 \mathrm{~m}$ downstream from a site of gold washing. Drilling waters were selected in each mining town/village. At each river and stream sampling point, approximately $1.5 \mathrm{ml}$ of water was taken from the center of the stream/river to a depth of approximately 10 to $20 \mathrm{~cm}$ below the water surface. Sediment samples weighing about 300 grams were also below the water surface from the center of the stream/river. The drilling water samples were taken directly from the well heads. The drill pipe was pumped out before taking the sample, the samples were taken directly. The water samples were stored in polypropylene bottles which were rinsed with $10 \% \mathrm{HNO}_{3}$. Approximately $3 \mathrm{~cm}^{3}$ of concentrated $\mathrm{HNO}_{3}$ was added to the water samples to stabilize the mercury and cyanide content. The sediment samples were collected in pre-labeled transparent polythene bags. All samples were stored in an ice chest with ice to maintain a low temperature $\left(4^{\circ} \mathrm{C}\right)$ during transport to the CIAPOL Laboratory, Cote d'Ivoire.

\subsection{Laboratory Analyses}

Laboratory analyses were carried out according to procedures defined by [8]. Total mercury analysis was carried out at the CIAPOL Laboratory by Atomic Emission Spectrometer Inductively Plasma Coupled (ICP-AES).

\subsubsection{Analyses of TME in Water Samples}

The analysis of mercury and cyanide was by Inductive Coupled Plasma Atomic Emission Spectrometer (ICP-AES), which consist of the measurement of light radiation from a given element after artificial excitation. Indeed, fine amounts of the water samples will be absorbed by a tube and sprayed onto the optical path of the spectrometer. By emission of light at wavelengths specific to the TME being assayed, they are excited. Their return to a stable state will be preceded by an emission of light radiation which was picked up by a detector which will allow the concentration reading of the measured TMEs. The results of the analysis of the samples will be compared to the standards proposed by the water quality [7].

\subsubsection{Analyses for Trace Metal Elements (TME) in Sediments}

After drying of the sediments in an oven at a temperature of $50^{\circ} \mathrm{C}$ for 24 hours, the samples were sieved on $2 \mathrm{~mm}$ mesh size sieve to eliminate the coarse elements. They are then ground using an agate mortar and sifted to obtain a powder with particle diameter of less than $63 \mu \mathrm{m}$. The powder is then subjected to digestion. The digestion method used in this study is that of total decomposition recommended by [9]. The concentration of TMEs ( $\mathrm{Hg}$ and $\mathrm{CN})$ was determined by atomic emission spectrometry using an argon plasma source generated by inductive coupling (ICP-AES) (C). 


\subsubsection{Calculation of Metal Enrichment Indices}

The evaluation of the degree of metallic contamination and of the toxicity of surface sediments was based on the calculation of the metallic and polymetallic enrichment indices, in particular: the contamination factor (CF), the modified degree of contamination $\left(\mathrm{DC}_{\mathrm{m}}\right)$, the sediment toxicity index or sediment pollution index (SPI).

\section{1) Calculation of the Contamination Factor}

The contamination factor is used to show the existence or absence of contamination of sediments by trace elements. It also makes it possible to give the level of contamination if it exists [10] [11]. This contamination factor is expressed by the following formula:

$$
\mathrm{CF}=\frac{\mathrm{C}_{\text {metal }}}{\mathrm{C}_{\text {reference }}}
$$

$\mathrm{C}_{\text {metal }}$ : Concentration measured for a metal

$\mathrm{C}_{\text {reference: }}$ Reference concentration of the metal

[12] defined CF contamination classes (Table 1).

\section{2) Determination of the degree of contamination (DC)}

The degree of contamination (DC) is the sum of the CFs [12].

According to [13], it allows the estimation of the a priori polymetallic contamination for each sampling point. This degree of contamination is expressed by the following formula:

$$
\mathrm{DC}_{\mathrm{i}}=\sum \mathrm{CF}
$$

The use of this formula requires consideration of metallic and organic pollutants. In order to generalize the formula, [14] modified it and adapted it to the number of analyzed pollutants. The modified contamination degree $\left(\mathrm{DC}_{\mathrm{m}}\right)$ is determined at each site by the sum of the contamination factors (CF) divided by the number of analyzed pollutants. It is expressed by the following formula:

$$
\mathrm{DC}_{\mathrm{m}}=\frac{\sum \mathrm{CF}}{\mathrm{n}}
$$

where n: number of analyzed pollutants.

The $\mathrm{DC}_{\mathrm{m}}$ is associated with seven (07) classes according to [14] (Table 2).

\section{3) Calculation of the Sediment Pollution Index (SPI)}

The calculation of the enrichment factors makes it possible to obtain information on the contamination of the sediments but does not take into account the concept of toxicity linked to each metal.

Table 1. Contamination factor classes [8].

\begin{tabular}{ccc}
\hline Class & Value & Sediment pollution intensity \\
\hline 1 & $\mathrm{CF}<1$ & Goes away with weak \\
2 & $1 \leq \mathrm{CF}<3$ & Moderated \\
3 & $3 \leq \mathrm{CF}<6$ & Considerable \\
4 & $6 \leq \mathrm{CF}$ & Very strong \\
\hline
\end{tabular}


Table 2. Classes of the degree of contamination modified according to [14].

\begin{tabular}{ccc}
\hline Class & Value & Sediment pollution intensity \\
\hline 1 & $\mathrm{DC}_{\mathrm{m}}<1.5$ & Zero degree of contamination to very low level \\
2 & $1.5<\mathrm{DC}_{\mathrm{m}}<2$ & Low degree of contamination \\
3 & $2<\mathrm{DC}_{\mathrm{m}}<4$ & Moderate degree of contamination \\
4 & $4<\mathrm{DC}_{\mathrm{m}}<8$ & High degree of contamination \\
5 & $8<\mathrm{DC}_{\mathrm{m}}<16$ & Very high degree of contamination \\
6 & $16<\mathrm{DC}_{\mathrm{m}}<32$ & Extremely high degree of contamination \\
7 & $\mathrm{DC}_{\mathrm{m}} \geq 32$ & Ultra-high degree of contamination \\
\hline
\end{tabular}

Table 3. Sediment pollution index (SPI) classes.

\begin{tabular}{ccc}
\hline Class & Value & Sediment pollution intensity \\
\hline 1 & $0 \leq$ IPS $<2$ & Healthy sediment \\
2 & $2 \leq$ IPS $<5$ & Slightly polluted sediment \\
3 & $5 \leq$ IPS $<10$ & Moderately polluted sediment \\
4 & $10 \leq$ IPS $<20$ & Very polluted sediment \\
5 & $20 \leq$ IPS & Dangerous sediment \\
\hline
\end{tabular}

Thus, [15] introduced the sediment pollution index (SPI). This index is defined as a linear sum of the CF and takes into account the relative toxicity of the TME by a weighting factor $(\mathrm{W})$. A weight of 1 is assigned to $\mathrm{Zn}$ because it is the least toxic; $\mathrm{Cr}$ the value $2 ; \mathrm{Pb}$ and $\mathrm{Cu}$ are assigned the value 5 and $\mathrm{Cd}$ the value 30 [12]. The SPI can be expressed by the following equation:

$$
\mathrm{SPI}_{\mathrm{n}}=\left(\frac{\sum \mathrm{FC}_{\mathrm{n}} \times \mathrm{W}_{\mathrm{n}}}{\sum \mathrm{W}_{\mathrm{n}}}\right)
$$

$\mathrm{FC}_{\mathrm{n}}$ : metal contamination factor $\mathrm{n}$

$\mathrm{W}_{\mathrm{n}}$ : weight assigned to the metal considered

SPI is associated with five (05) quality classes [16] (Table 3).

\section{Results}

Comparisons were made between the waters, then the sediments. Comparisons were also made between wet and dry season averages [1] for surface water, boreholes and sediment samples.

In addition, the results of the water samples were compared with the [7] guideline value $(6 \mu \mathrm{g} / \mathrm{L})$ for mercury and $(70 \mu \mathrm{g} / \mathrm{L})$ for cyanide for drinking water and that of sediments samples were compared to the [17] guideline value $(0.2$ $\mathrm{mg} / \mathrm{kg}$ for mercury and $0.07 \mathrm{mg} / \mathrm{kg}$ for cyanide). Finally, comparisons were made with the results of studies conducted elsewhere with similar characteristics. The results of the total mercury and cyanide analysis for the study periods are presented in Table 4 and Figures 4-6. Concentrations that fall above safe limits are identified and discussed. 
Table 4. Comparison of Mean Concentrations of Total Mercury and Cyanide ( $\mu \mathrm{g} / \mathrm{L})$ in Stream/River Water Samples.

\begin{tabular}{|c|c|c|c|c|c|c|}
\hline \multirow{2}{*}{ Localités } & \multicolumn{3}{|c|}{ Mercure } & \multicolumn{3}{|c|}{ Cyanide } \\
\hline & Wet saeson & Dry season & Mean & Wet saeson & Dry season & Mean \\
\hline HR5 & -0.0126 & 4.98 & 2.3137 & 0.002 & $<0.06$ & 0.002 \\
\hline HR4 & -0.003 & 0 & -0.0015 & $<0.002$ & $<0.06$ & 0 \\
\hline HR1 & 0.498 & 0 & 0.249 & $<0.002$ & $<0.06$ & 0 \\
\hline HR6 & -0.0277 & 0 & -0.01385 & $<0.002$ & $<0.06$ & 0 \\
\hline HR7 & -0.0013 & 0 & -0.00065 & 75 & 80 & 77.5 \\
\hline HR2 & -0.0094 & 0 & -0.0047 & $<0.002$ & $<0.06$ & 0 \\
\hline HR8 & -0.0197 & 0 & -0.00985 & $<0.002$ & $<0.06$ & 0 \\
\hline HR3 & -0.012 & 0 & -0.006 & $<0.002$ & $<0.06$ & 0 \\
\hline AR2 & -0.0116 & 0 & -0.0058 & $<0.002$ & $<0.06$ & 0 \\
\hline ZR3 & -0.011 & 0 & -0.0055 & $<0.002$ & $<0.06$ & 0 \\
\hline R3 & -0.008 & 0 & -0.004 & 0.003 & $<0.06$ & 0.003 \\
\hline IR & 0.0051 & 2.64 & 1.32255 & 0.003 & $<0.06$ & 0.003 \\
\hline $\mathrm{R} 2$ & 0.0137 & 1.67 & 0.84185 & $<0.002$ & $<0.06$ & 0 \\
\hline ZR2 & -0.0119 & 0 & -0.00595 & 0.006 & $<0.06$ & 0.006 \\
\hline ZR1 & -0.0132 & 4.64 & 2.4834 & $<0.002$ & $<0.06$ & 0 \\
\hline AR1 & -0.0074 & 2.34 & 1.1663 & 95 & 50 & 72.5 \\
\hline BRR & -0.0162 & 0 & -0.0081 & 0.007 & $<0.06$ & 0.007 \\
\hline GR & -0.0095 & 1.56 & 0.77525 & 0.003 & $<0.06$ & 0.003 \\
\hline NR1 & -0.0128 & 0 & -0.0064 & $<0.002$ & $<0.06$ & 0 \\
\hline NR2 & -0.0029 & 0 & -0.00145 & 0.005 & $<0.06$ & 0.005 \\
\hline BR1 & -0.0174 & 0 & -0.0087 & $<0.002$ & $<0.06$ & 0 \\
\hline DVR & 0.0301 & 0 & 0.01505 & $<0.002$ & $<0.06$ & 0 \\
\hline KGR1 & -0.0113 & 0 & -0.00565 & $<0.002$ & $<0.06$ & 0 \\
\hline DOR & -0.0099 & 3.391 & 1.69055 & $<0.002$ & $<0.06$ & 0 \\
\hline KGR2 & -0.0088 & 0 & -0.0044 & $<0.002$ & $<0.06$ & 0 \\
\hline BR2 & -0.0076 & 2.64 & 1.3162 & $<0.002$ & $<0.06$ & 0 \\
\hline MR & -0.0112 & 3.31 & 1.6494 & 0.006 & $<0.06$ & 0.006 \\
\hline
\end{tabular}

\subsection{Mercury and Cyanide in River/Stream Water}

All mercury concentrations recorded during the rainy season are lower than the corresponding concentrations during the dry season Table 4 . The difference in mercury concentration between seasons is significant at $5 \%$. As for the cyanide concentrations, they are approximately equal over the two seasons.

The concentrations of mercury in the rainy season do not exceed the [7] guideline value $(6 \mu \mathrm{g} / \mathrm{L})$ for drinking water. These results show that all mercury 
concentrations obtained in rivers and streams are in line with [7] guide values for drinking water. The highest concentration is recorded at the HR1 site $(0.498$ $\mu \mathrm{g} / \mathrm{L}$ ). The Hg concentrations recorded in dry season vary between 0 and 4.98 $\mu \mathrm{g} / \mathrm{L}$ respectively at the level of ZHR3 (outside mining sites) and HR5 (near mining sites). High concentrations of cyanide were recorded on the HR7 (80 $\mu \mathrm{g} / \mathrm{L}$ in the dry season) and AR1 (95 $\mu \mathrm{g} / \mathrm{L}$ in the wet season). These stations are located respectively near a gold mining site in Hiré and downstream from the Agbaou industrial mining site (Figure 4 and Figure 5).

This reveals systematic seasonal variations in mercury concentrations and the increase in total mercury.

The spatial distribution map of the cyanide content is presented by the Figure 6. On this map, the highest cyanide values are located in the mining area, hence the direct effect of this metal in the surface waters.

\subsection{Mercury and Cyanide in Groundwater}

These results show that all mercury and cyanide concentrations in wells and drills are in line with [7] guide values for drinking water. During wet and dry seasons, cyanide concentrations remained lower than [7] standards for drinking water. Trends in mercury concentrations showed maximum values at AGPU

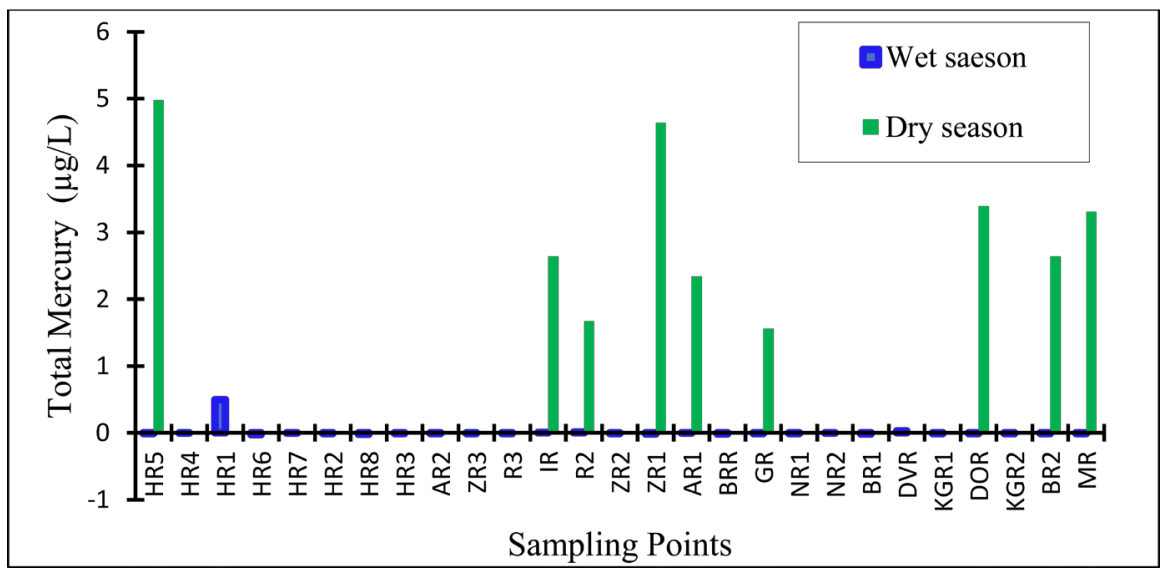

Figure 4. Total mercury analysis of stream/river water samples.

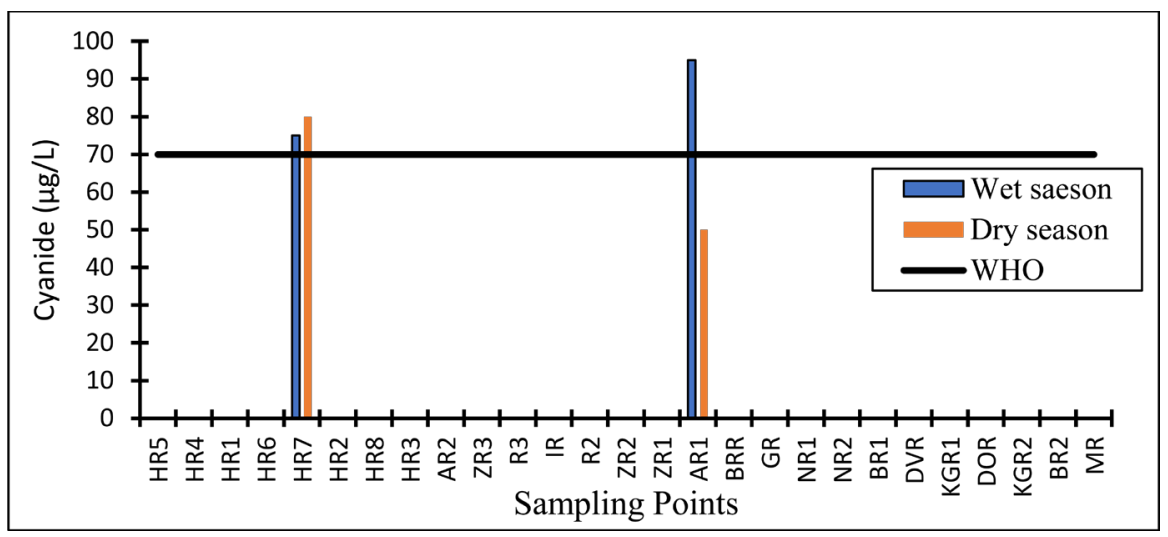

Figure 5. Cyanide analysis of stream/river water samples. 
$(3.67 \mu \mathrm{g} / \mathrm{L})$. This well water is located in the village of Agbaou downstream of the site of treatment of gold. The average mercury values for the two seasons are $0.0087 \mu \mathrm{g} / \mathrm{L}$ (wet season) and $1.05 \mu \mathrm{g} / \mathrm{L}$ (dry season). The mercury levels measured during the rainy season are lower than the corresponding dry season. The concentrations of mercury during the wet season are lower than the standards of $6 \mu \mathrm{g} / \mathrm{L}$ (Figure 7 and Table 5).

\subsection{Mercury and Cyanide in Surface Sediments}

The results of the determination of mercury and cyanide in surface sediments

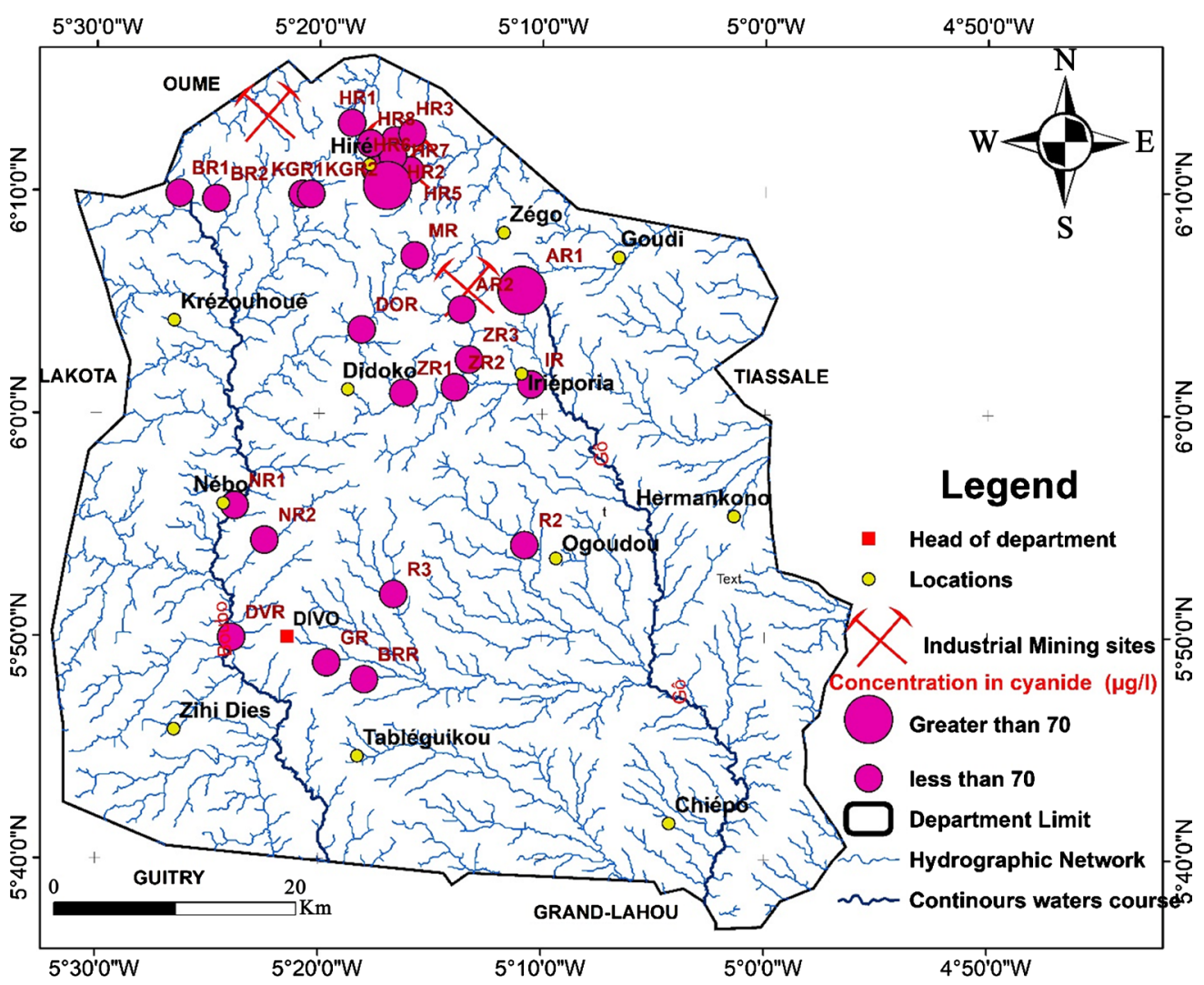

Figure 6. Space distribution of cyanide content in the surface waters of the diver.

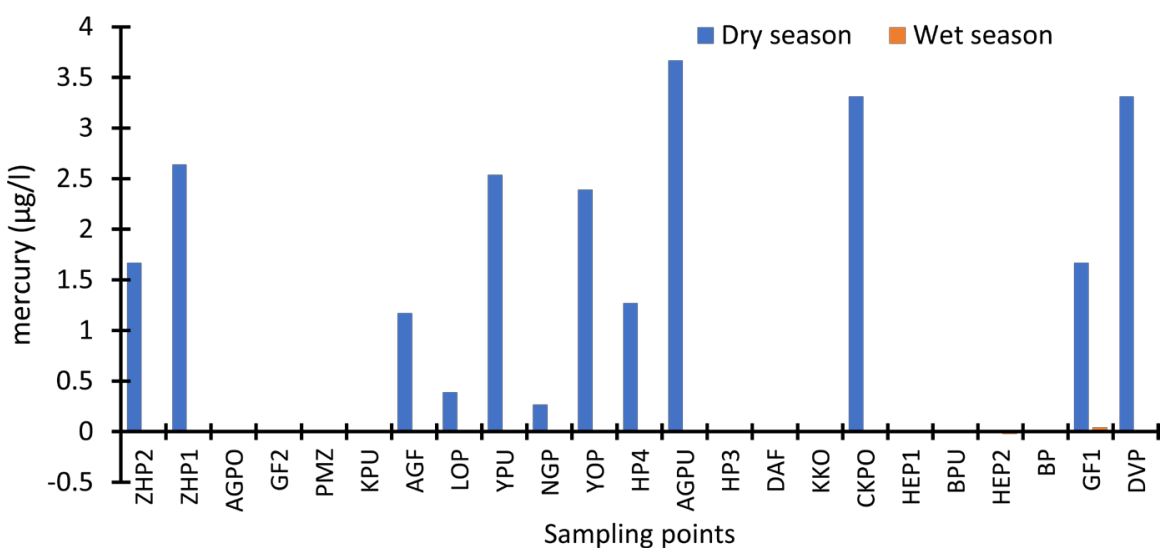

Figure 7. Total mercury analysis of groundwater water samples. 
Table 5. Comparison of mean concentrations of total mercury and cyanide $(\mu \mathrm{g} / \mathrm{L})$ in groundwater water samples.

\begin{tabular}{|c|c|c|c|c|c|c|}
\hline \multirow{2}{*}{ Localités } & \multicolumn{3}{|c|}{ Cyanide } & \multicolumn{3}{|c|}{ Mercury } \\
\hline & Dry season & Wet season & Mean & Dry season & Wet season & Mean \\
\hline ZHP2 & $<0.06$ & $<0.002$ & $<0.002$ & 1.67 & -0.007 & 0.8315 \\
\hline ZHP1 & $<0.06$ & $<0.002$ & $<0.002$ & 2.64 & -0.0136 & 1.31 \\
\hline AGPO & $<0.06$ & $<0.002$ & $<0.002$ & $<1$ & -0.0022 & -0.0022 \\
\hline GF2 & $<0.06$ & 0.016 & $<0.002$ & $<1$ & -0.0093 & -0.0093 \\
\hline PMZ & $<0.06$ & $<0.002$ & $<0.002$ & $<1$ & 0 & 0 \\
\hline KPU & $<0.06$ & 0.009 & $<0.002$ & $<1$ & -0.0067 & -0.0067 \\
\hline AGF & $<0.06$ & $<0.002$ & $<0.002$ & 1.17 & -0.0032 & 0.5834 \\
\hline LOP & $<0.06$ & $<0.002$ & $<0.002$ & 0.39 & -0.0078 & 0.1911 \\
\hline YPU & $<0.06$ & $<0.002$ & $<0.002$ & 2.539 & 0 & 1.27 \\
\hline NGP & $<0.06$ & $<0.002$ & $<0.002$ & 0.268 & 0 & 0.268 \\
\hline YOP & $<0.06$ & $<0.002$ & $<0.002$ & 2.391 & -0.011 & 1.19 \\
\hline HP4 & $<0.06$ & $<0.002$ & $<0.002$ & 1.268 & 0 & 1.27 \\
\hline AGPU & $<0.06$ & $<0.002$ & $<0.002$ & 3.67 & 0.0087 & 1.83 \\
\hline HP3 & $<0.06$ & $<0.002$ & $<0.002$ & $<1$ & 0 & 0 \\
\hline DAF & $<0.06$ & $<0.002$ & $<0.002$ & $<1$ & -0.0162 & -0.0162 \\
\hline KKO & $<0.06$ & $<0.002$ & $<0.002$ & $<1$ & -0.007 & -0.0068 \\
\hline CKPO & $<0.06$ & $<0.002$ & $<0.002$ & 3.31 & -0.0059 & 1.65 \\
\hline HEP1 & $<0.06$ & $<0.002$ & $<0.002$ & $<1$ & -0.009 & -0.0087 \\
\hline BPU & $<0.06$ & $<0.002$ & $<0.002$ & $<1$ & 0 & 0 \\
\hline HEP2 & $<0.06$ & $<0.002$ & $<0.002$ & $<1$ & -0.023 & -0.02314 \\
\hline $\mathrm{BP}$ & $<0.06$ & $<0.002$ & $<0.002$ & $<1$ & -0.0074 & -0.0074 \\
\hline GF1 & $<0.06$ & 0 & $<0.002$ & 1.67 & 0.045 & 0.8575 \\
\hline DVP & $<0.06$ & 0 & $<0.002$ & 3.31 & -0.0161 & 1.65 \\
\hline
\end{tabular}

are presented in the table. All mercury concentrations measured in the dry season are higher than the corresponding concentrations in the wet season, with the exception of a few points (Table 6).

In the case of rivers near mining sites, the mercury concentration in the rainy season of the HR5 $(0.7 \mathrm{mg} / \mathrm{kg}), \mathrm{HR} 1(0.5 \mathrm{mg} / \mathrm{kg})$ and HR2 $(0.3 \mathrm{mg} / \mathrm{kg})$ sites are higher than the dry season mercury concentrations with respective values 0.002 $\mathrm{mg} / \mathrm{kg} ; 0.041 \mathrm{mg} / \mathrm{kg}$ and $0.033 \mathrm{mg} / \mathrm{kg}$. The difference in total mercury concentration between wet and dry seasons is significant.

Like mercury, the cyanide concentrations of the different samples in the dry season are higher than the corresponding concentrations in the rainy seasons, with the exception of the sites HR7 $(0.80 \mathrm{mg} / \mathrm{kg}), \mathrm{R} 3(0.65 \mathrm{mg} / \mathrm{kg})$ and R2 $(0.75$ $\mathrm{mg} / \mathrm{kg}$ ). Mercury concentrations in sediment samples collected near mining 
Table 6. Comparison of the mean concentrations of total Mercury and cyanide (mg/kg).

\begin{tabular}{|c|c|c|c|c|c|c|}
\hline \multirow{2}{*}{ Localités } & \multicolumn{3}{|c|}{ Cyanide } & \multicolumn{3}{|c|}{ Mercury } \\
\hline & Dry season & Wet season & Mean & Dry season & Wet season & Mean \\
\hline HR1 & 0.032 & 0.08 & 0.0545 & 0.41 & 0.50 & 0.1409 \\
\hline HR2 & 0.039 & 0.00 & 0.0205 & 0.33 & 0.30 & 0.0789 \\
\hline HR3 & 0 & 0.04 & 0.0215 & 0 & 0.00 & 0.0129 \\
\hline HR4 & 0.125 & 0.04 & 0.08 & 0.053 & 0.00 & 0.0586 \\
\hline HR5 & 0.026 & 0.00 & 0.014 & 0.002 & 0.70 & 0.1488 \\
\hline HR6 & 0.005 & 0.00 & 0.0035 & 0.21 & 0.00 & 0.0063 \\
\hline HR7 & 0.02 & 0.80 & 0.41 & 0.011 & 0.00 & 0.2482 \\
\hline HR8 & 0 & 0.10 & 0.049 & 0 & 0.00 & 0.0294 \\
\hline ZR1 & 0.125 & 0.00 & 0.0625 & 0.027 & 0.03 & 0.0489 \\
\hline ZR2 & 0.02 & 0.10 & 0.06 & 0.005 & 0.00 & 0.037 \\
\hline ZR3 & 0.01 & 0.01 & 0.009 & 0.005 & 0.01 & 0.0084 \\
\hline $\mathrm{R} 3$ & 0.017 & 0.65 & 0.3335 & 0.004 & 0.03 & 0.2069 \\
\hline IR & 0.024 & 0.07 & 0.0485 & 0.003 & 0.00 & 0.0297 \\
\hline AR2 & 0.178 & 0.00 & 0.089 & 0.034 & 0.04 & 0.0682 \\
\hline AR1 & 0.074 & 0.01 & 0.0435 & 0.008 & 0.04 & 0.0357 \\
\hline $\mathrm{R} 2$ & 0.379 & 0.75 & 0.5625 & 0.045 & 0.00 & 0.3465 \\
\hline GR & 0.159 & 0.06 & 0.1075 & 0.026 & 0.00 & 0.0697 \\
\hline BRR & 0 & 0.00 & 0 & 0 & 0.00 & 0 \\
\hline DOR & 0.19 & 0.06 & 0.126 & 0 & 0.00 & 0.0756 \\
\hline DVR & 0.041 & 0.00 & 0.0215 & 0.011 & 0.00 & 0.0151 \\
\hline KGR1 & 0.157 & 0.01 & 0.0845 & 0.027 & 0.00 & 0.0561 \\
\hline $\mathrm{BR} 1$ & 0.041 & 0.00 & 0.0215 & 0.007 & 0.00 & 0.0143 \\
\hline BR2 & 0.047 & 0.05 & 0.0495 & 0.008 & 0.00 & 0.0313 \\
\hline NR1 & 0.059 & 0.05 & 0.0555 & 0.007 & 0.00 & 0.0347 \\
\hline NR2 & 0.118 & 0.01 & 0.0655 & 0.028 & 0.00 & 0.0449 \\
\hline MR & 0.134 & 0.07 & 0.1035 & 0.067 & 0.00 & 0.0755 \\
\hline KGR2 & 0.111 & 0.09 & 0.1015 & 0.016 & 0.03 & 0.0701 \\
\hline
\end{tabular}

areas during wet and dry seasons exceed the [17] guideline value of $0.2 \mathrm{mg} / \mathrm{kg}$ with the exception of HR4 sites $(0.053 \mathrm{mg} / \mathrm{kg})$ and HR3 $(00 \mathrm{mg} / \mathrm{kg})$ during the rainy season. The highest mercury concentration of $0.7 \mathrm{mg} / \mathrm{kg}$ was recorded about $200 \mathrm{~km}$ from a gold mining site during the wet season while the lowest $(0$ $\mathrm{mg} / \mathrm{kg}$ ) was recorded in several samples outside mining areas during the rainy and dry season. The highest cyanide concentration of $0.80 \mathrm{mg} / \mathrm{kg}$ was recorded in a sample located near a gold mining site during the rainy season and the lowest $(0 \mathrm{mg} / \mathrm{kg})$ was also recorded in several samples outside mining areas during both seasons. 
The high concentrations recorded in the sediments during the dry season are due to the increase in mining activities during the dry season with a corresponding increase in the use of mercury. The other reason is the evaporation of surface water resulting from increased concentrations of mercury in water and sediment. As for the high concentrations recorded during the wet season is due to the phenomenon of erosion, with the flow of surface water from mining sites to surrounding waterways.

\subsection{Assessment of Sediment Contamination}

The results of the calculations of the metal enrichment indices during the two seasons are presented in Table 7 . The results of the table show often very high

Table 7. CF, DC $\mathrm{m}$ and IPS values of surface sediments.

\begin{tabular}{|c|c|c|c|c|c|c|c|c|}
\hline \multirow{2}{*}{ Localités } & \multicolumn{4}{|c|}{ Wet season } & \multicolumn{4}{|c|}{ Dry season } \\
\hline & $\mathrm{FC}(\mathrm{CN})$ & $\mathrm{FC}(\mathrm{Hg})$ & $\mathrm{DC}_{\mathrm{m}}$ & IPS & $\mathrm{FC}(\mathrm{CN})$ & $\mathrm{FC}(\mathrm{Hg})$ & $\mathrm{DC}_{\mathrm{m}}$ & IPS \\
\hline HR1 & 2.57 & 8.93 & 5.75 & 11.50 & 0.62 & 0.82 & 0.72 & 2.16 \\
\hline HR2 & 0.07 & 5.36 & 2.71 & 5.42 & 0.73 & 0.98 & 0.86 & 2.57 \\
\hline HR3 & 1.43 & 0.00 & 0.72 & 1.43 & 0.00 & 0.00 & 0.00 & 0.00 \\
\hline HR4 & 1.17 & 0.00 & 0.58 & 1.17 & 1.96 & 2.62 & 2.29 & 6.87 \\
\hline HR5 & 0.07 & 12.50 & 6.28 & 12.57 & 0.39 & 0.52 & 0.45 & 1.35 \\
\hline HR6 & 0.07 & 0.00 & 0.03 & 0.07 & 0.23 & 0.31 & 0.27 & 0.81 \\
\hline HR7 & 2.67 & 0.00 & 1.33 & 2.67 & 0.37 & 0.49 & 0.43 & 1.29 \\
\hline HR8 & 3.27 & 0.00 & 1.63 & 3.27 & 0.00 & 0.00 & 0.00 & 0.00 \\
\hline ZR1 & 0.00 & 0.54 & 0.27 & 0.54 & 1.99 & 2.66 & 2.32 & 6.97 \\
\hline ZR2 & 3.33 & 0.00 & 1.67 & 3.33 & 0.32 & 0.43 & 0.38 & 1.13 \\
\hline ZR3 & 0.27 & 0.18 & 0.22 & 0.45 & 0.18 & 0.24 & 0.21 & 0.63 \\
\hline R3 & 21.67 & 0.54 & 11.10 & 22.20 & 0.27 & 0.36 & 0.32 & 0.96 \\
\hline IR & 2.43 & 0.00 & 1.22 & 2.43 & 0.37 & 0.49 & 0.43 & 1.28 \\
\hline AR2 & 0.00 & 0.71 & 0.36 & 0.71 & 1.12 & 1.49 & 1.30 & 3.91 \\
\hline AR1 & 0.43 & 0.71 & 0.57 & 1.15 & 2.71 & 3.62 & 3.17 & 9.50 \\
\hline $\mathrm{R} 2$ & 24.87 & 0.00 & 12.43 & 24.87 & 1.31 & 1.75 & 1.53 & 4.60 \\
\hline GR & 1.87 & 0.00 & 0.93 & 1.87 & 2.80 & 3.74 & 3.27 & 9.81 \\
\hline BRR & 0.00 & 0.00 & 0.00 & 0.00 & 0.00 & 0.00 & 0.00 & 0.00 \\
\hline DOR & 2.07 & 0.00 & 1.03 & 2.07 & 0.67 & 0.89 & 0.78 & 2.34 \\
\hline DVR & 0.07 & 0.00 & 0.03 & 0.07 & 5.76 & 7.68 & 6.72 & 20.16 \\
\hline KGR1 & 0.40 & 0.00 & 0.20 & 0.40 & 2.45 & 3.27 & 2.86 & 8.57 \\
\hline BR1 & 0.07 & 0.00 & 0.03 & 0.07 & 0.64 & 0.85 & 0.75 & 2.24 \\
\hline BR2 & 1.73 & 0.00 & 0.87 & 1.73 & 0.59 & 0.79 & 0.69 & 2.08 \\
\hline NR1 & 1.73 & 0.00 & 0.87 & 1.73 & 0.90 & 1.20 & 1.05 & 3.14 \\
\hline NR2 & 0.43 & 0.00 & 0.22 & 0.43 & 1.90 & 2.53 & 2.22 & 6.65 \\
\hline MR & 2.43 & 0.00 & 1.22 & 2.43 & 2.12 & 2.83 & 2.47 & 7.42 \\
\hline KGR2 & 3.07 & 0.54 & 1.80 & 3.60 & 1.71 & 2.28 & 1.99 & 5.98 \\
\hline
\end{tabular}


values of the indices at certain points.

In the rainy season, the Contamination Factor $(\mathrm{CF})$ values vary from 0 at station ZR1 and 24.87 at station R2 for CN. As for mercury, the Contamination Factor (CF) values vary from 0 at the IR station and 12.50 at the HR5 station. The sediments of the stations studied show a low contamination absent $(\mathrm{CF} \geq 1)$ for the TME studied and very strong contaminations $(6 \leq \mathrm{CF})$ are observed at some stations. The modified Degree of Contamination $\left(\mathrm{DC}_{\mathrm{m}}\right)$ values vary from 0 at station BRR to 12.43 at station R2. These values indicate the presence of considerable contamination $\left(\mathrm{DC}_{\mathrm{m}}=12.43\right)$ at station $\mathrm{R} 2$ and low contamination $\left(\mathrm{DC}_{\mathrm{m}}<6\right)$ at the other stations of studies.

Regarding the Sediment Pollution Index (SPI), the values vary between 0.07 at station HR6 and 24.87 at station R2. Overall, the SPI values show that the surface sediments are moderately polluted except those at stations HR1, HR5, R2 and R3 which are heavily polluted sediments. These stations have SPI values $\geq 10$.

In the dry season, the Contamination Factor $(\mathrm{CF})$ values vary from 0 at the HR3 station and 5.76 at the DVR station for CN. As for mercury, the values of the Contamination Factor (CF) vary from 0 at station HR3 and 3.74 at station GR. The sediments of the stations studied show an absent to low contamination $(\mathrm{CF} \geq 1)$ for the TME studied and considerable contamination $(3 \leq \mathrm{CF}<6)$ is observed on some stations. Modified Contamination Degree $\left(\mathrm{DC}_{\mathrm{m}}\right)$ values vary from 0 at the BRR station to 6.72 at the DVR station. These values indicate the presence of a moderate contamination $\left(\mathrm{DC}_{\mathrm{m}}=6.72\right)$ to station $\mathrm{DVR}$ and of a weak contamination $\left(\mathrm{DC}_{\mathrm{m}}<6\right.$ at the other. These values indicate the presence of moderate contamination $\left(\mathrm{DC}_{\mathrm{m}}=6.72\right)$ at the DVR station and low contamination $\left(\mathrm{DC}_{\mathrm{m}}<6\right)$ at the other stations of studies. Regarding the Sediment Pollution Index (SPI), the values vary between 0 at the BRR station and 20.16 at the DVR station.

Overall, the SPI values show that the surface sediment is moderately polluted except from the DVR station, which is a heavily polluted sediment with a value of SPI $\geq 10$.

\section{Discussion}

The high concentration of mercury recorded at the HR5 station $(4.98 \mu \mathrm{g} / \mathrm{L})$, as well as in other stations, is lower than the average reference concentration of the study area set to $6 \mu \mathrm{g} / \mathrm{L}$ [7]. Cyanide and mercury are present in the natural water of the department, but at concentrations that meet the standards for drinking water. These elements are strongly present in water, when they are of anthropic origin, originating respectively from cyanide leaching and mercury amalgamation used to separate gold from waste rock during ore processing.

According to [18], with the phenomenon of pluviolessivage, the metallic elements are entrained in the water. According to [17], people who drink water containing $\mathrm{Hg}$ well above the maximum contaminant level for many years could experience kidney damage. Our results work with those of [19] in the mining area of Zouan-Hounien (West Coast of Ivory Coast). 
The results of analyses of mercury and cyanide in the surface sediments of the department show that stations (R2, HR5, GR, DVR and HR7) are subjected to anthropic pressures. These stations present higher average concentrations of $\mathrm{Hg}$ and $\mathrm{CN}$ than the other study stations. The concentrations of the studied ETM are higher than the average values of reference defined by directive EPA of the United States.

The concentrations of the TME studied are higher than the average reference values defined by the United States EPA directive. This trend is confirmed by the results of the various calculated indices ( $\mathrm{DC}_{\mathrm{m}}$ and IPS). Variations in TME concentrations are affected by multiple factors such as natural and anthropic sources. These same observations were made by [20] in the mining field in Ghana.

\section{Conclusion}

Mining has for some time been highly developed in Ivory Coast. The Department of Divo is one of the main metallogenic provinces of the country. There are several industrial mining sites in operation, more specifically in Hiré and Agbaou. Several gold-bearing lenses have been identified, some of which are in operation by mining companies such as: Endeavour Mining and Agbaou Gold mine. The present study made it possible to highlight the level of contamination of water and surface sediments by mercury and cyanide. It should be noted that the waters and sediments in the study area are contaminated with $\mathrm{CN}$ and $\mathrm{Hg}$ in some cases and not contaminated at other sites. This contamination is expressed by the high contamination factor and high IPS values. These results reflect an enrichment of elements of anthropic origin compared to the average levels of the UCC. Enrichment would be linked to mining activity. More detailed studies on the water and types of fertilizers, then the products used in general during mining activities in the department will support these presumptions. While waiting for, it is obvious that this water is not appropriate for human consumption. Their consumption without prior treatment exposes the population to health risks.

\section{Acknowledgements}

The authors thank the international joint laboratory LMI MINERWA, the international network AMEDEE, the Laboratory of Soil, Water and Geomaterials Sciences (LSSEG) of the Félix Houphouët Boigny University of Abidjan and the analysis laboratory of the IRD of Nangui Abrogoua University for data analyses.

\section{Conflicts of Interest}

The authors declare no conflicts of interest regarding the publication of this paper.

\section{References}

[1] MINEO (2008) User Need Document. Part 2, Potential Environmental and Social Impact of Mining. $28 \mathrm{p}$.

[2] Marusczak, N. (2010) Etude du transfert du mercure et du méthylmercure dans les 
écosystèmeslacustresalpins. Thèse de doctorat, Sciences de la Terre et de l'Univers et de l'Environnement, Université de Grenoble, 207 p.

[3] Scheuhammer, A.M., Evers, D.C., Heinz, G.H., et al. (2012) Ecotoxicology of Mercury in Fish and Wildlife: Recent Advances. In: Toxicology, Risk Analysis, Humans, and Policy, University of California Press, Berkley, 223-238.

[4] Bhuyan, Md.S., Bakar, M.A., Rashed, U.N.Md., Senapath, V., Chung, S.Y. and Islam, Md.S. (2019) Monitoring and Assessment of Heavy Metal Contamination in Surface Water and Sediment of the Old Brahmaputra River, Bangladesh. Applied Water Science, 9, 125. https://doi.org/10.1007/s13201-019-1004-y

[5] Bell, L., DiGangi, J. and Weinberg, J. (2014) Manuel d'introduction pour l'ONG à la pollution par le mercure et la convention de Minamata sur le mercure. 249 p.

[6] Diop, M., Howsam, M., Diop, C., Goossens, J.F., Diouf, A. and Amara, R. (2016) Assessment of Trace Element Contamination and Bioaccumulation in Algae (Ulva lactuca), Mussels (Pernaperna), Shrimp (Penaeus kerathurus), and Fish (Mugil cephalus, Sarotherodon melanotheron) along the Senegalese Coast. Marine Pollution Bulletin, 103, 339-343. https://doi.org/10.1016/j.marpolbul.2015.12.038

[7] WHO (2017) Guidelines for Drinking-Water Quality. 4th Edition, World Health Organization, Geneva.

[8] Apha; awwa; wef (1998) Méthodes standard pour l'examen de l'eau et des eaux usées. 20e édition, American Public Health Association, Washington DC.

[9] Tessier, A., Campbel, P.G.C. and Bisson, M. (1979) Sequential Extraction Procedure for the Speciation of Particulate Traces Metals. Analytical Chemistry, 51, 844-851. https://doi.org/10.1021/ac50043a017

[10] Zhu, H.-N., Yuan, X.-Z., Zeng, G.-M., Jiang, M., Liang, J., Zhang, C., Yin, J., Huang, H.-J., Liu, Z.-F. and Jiang, H.-W. (2011) Ecological Risk Assessment of Heavy Metals in Sediments of Xiawan Port Based on Modified Potential Ecological Risk Index. Transactions of Nonferrous Metals Society of China, 22, 1470-1477. https://doi.org/10.1016/S1003-6326(11)61343-5

[11] Rezaie-boroon, M.H., Toress, V., Diaz, S., Lazzaretto, T., Tsang, M. and Deheyn, D.D. (2013) The Geochemistry of Heavy Metals in the Mudflat of Salinas de San Pedro Lagoon, California, USA. Journal of Environmental Protection, 4, 12-25. https://doi.org/10.4236/jep.2013.41002

[12] Hakanson, L. (1980) Ecological Risk Index for Aquatic Pollution Control. A Sedimentological Approach. Water Research, 14, 975-1001. https://doi.org/10.1016/0043-1354(80)90143-8

[13] Sahli, L., El Okki, M.E.H., Afri-Mehennaoui, F.-Z. and Mehennaoui, S. (2014) Utilisationd'indices pour l'évaluation de la qualité des sédiments: Cas Du BassinBoumerzoug (Algerie). European Scientific Journal, 10, 336-346.

[14] Abrahim, G.M.S. and Parker, R.J. (2008) Assessment of Heavy Metal Enrichment Factors and the Degree of Contamination in Marine Sediments from Tamaki Estuary, Auckland, New Zealand. Environmental Monitoring and Assessment, 136, 227-238. https://doi.org/10.1007/s10661-007-9678-2

[15] Rubio, B., Nombela, M.A. and Vilas, F. (2000) Geochemistry of Major and Trace Elements in Sediments of the Ria de Vigo (NW Spain): An Assessment of Metal Pollution. Marine Pollution Bulletin, 40, 968-980. https://doi.org/10.1016/S0025-326X(00)00039-4

[16] Singh, M., Müller, G. and Singh, I.B. (2002) Heavy Metals in Freshly Deposited Stream Sediments of Rivers Associated with Urbanisation of the Ganga Plain, India. 
Water, Air and Soil Pollution, 141, 35-54. https://doi.org/10.1023/A:1021339917643

[17] United State Environmental Protection Agency (USEPA) (2012) Basic Information about Lead in Drinking Water.

http://water.epa.gov/drink/contaminants/basicinformation/lead.cfm

[18] Eblin, S., Sombo, A.P., Soro, G., Aka, N., Kambire, O. and Soro, N. (2014) Hydrochimie des eaux de surface de la régiond'Adiaké (Sud-Est côtier de la Côte d'Ivoire). Journal of Applied Biosciences, 75, 6259-6271. https://doi.org/10.4314/jab.v75i1.10

[19] Djade, P.J.O., Traore, A., Koffi, K.J.T., Keumean, K.N., Soro, G. and Soro, N. (2020) Evaluation du niveau de contamination des eaux souterraines par les éléments traces métalliques dans le département de Zouan-Hounien (Ouest de la Côte d'Ivoire). Journal of Applied Biosciences, 150, 15457-15468.

https://doi.org/10.35759/JABs.150.6

[20] Nartey, V.K., Klake, R.K., Hayford, E.K., Doamekpor, L.K. and Appoh, R.K. (2011) Assessment of Mercury Pollution in Rivers and Streams around Artisanal Gold Mining Areas of the Birim North District of Ghana. Journal of Environmental Protection, 2, 1227-1239. https://doi.org/10.4236/jep.2011.29141 